Bangladesh Journal of Anatomy July 2011, Vol. 9 No. 2 pp 96-100

\title{
A Study on the Gonado Protective Role of Folinic Acid Against Cyclophosphamide Induced Cytotoxicity in Rat
}

\author{
Md. Afsan', Shahanaz Begum², AH Hamid Ahmed ${ }^{3}$
}

\begin{abstract}
Context: The inability to bear a child is a tragedy for many couples, bringing a sense of loss, failure and exclusion. Infertility is a global problem. Anticancer therapy with cyclophosphamide in a male leads to azoospermia. The present study was designed to observe the protective role of folinic acid against sterility in an animal model.
\end{abstract}

Study Design: Experimental study.

Place and Period of study: Department of Pharmacology, Bangabandhu Sheikh Mujib Medical University, Dhaka from July 1998 to June 1999.

Materials and method: The Gonadoprotective activity of folinic acid against Cyclophosphamide induced damage was studied in Long Evans Norwegian strain adult male rats. Rats were pretreated with Folinic acid (6 mg dissolved in $500 \mathrm{ml}$ of $5 \%$ dextrose in aqua) orally daily for 28 days. During the Folinic acid treatment, Cyclophosphamide (50 mg/kg body weight / day) was administered intraperitoneally at an interval of 24 hours from day 15 to day 28. Cytotoxic damage was assessed by estimation of body weight, testicular weight and volume and the histological findings.

Result : Pre-treatment with folinic acid plus cyclophosphamide produced significant increase in the number of seminiferous tubules, spermatozoa containing tubules and mean diameter of seminiferous tubules $(p<0.001)$.

Conclusion: Folinic acid provides significant protective role against Cyclophosphamide induced gonadal damage in Long Evans male rats.

Key words : Cyclophosphamide, Folinic acid

Introduction:

Infertility is a global problem. Infertility or sterility is an absolute state of inability to conceive. Among all cases of infertility in developed countries, about 8 percent can be traced to male factors, 37 percent can be due to female factors, and 35 percent can be due to factors in both the male and female partners. In about 5 percent of couples, the cause of infertility cannot be traced to specific factors in either partner ${ }^{1,2,3,4,5}$. About $90 \%$ of male infertility

1. Associate Professor \& Head, Dept. of Pharmacology and therapeutics, East West Medical College

2. Associate Professor \& Head, Dept of Anatomy, Shaheed Suhrawardy Medical College.

3. Assistant professor, Dept of Nephrology, BSMMU

Correspondence: Dr. Md. Afsan is caused by hypogonadism resulting in impaired spermatogenesis; and 80 to 90 percent of these men have isolated deficiency of sperm production with normal androgen production of unclear etiology, i.e, idiopathic oligospermia or azoospermia ${ }^{6}$. The morphological abnormalities include mostly of appearance of immature cells like spermatids and spermatocytes -these are the cells of previous lineage of spermatogenesis prior to spermatozoa ${ }^{7}$. During anticancer therapy with cyclophosphamide on male, similar to the feature of immature ejaculate syndrome appears $8,9,10$. Treatment with cyclophosphamide leads to azoospermia and disappearance of germinal epithelium with preservation of sertoli cells ${ }^{9}$. So, cyclophosphamide acts as gonado toxin in human and laboratory 
animal $^{10}$. Folinic acid therapy in 65 sterile males showed significant increase in spermatozoa number, motility, and decrease in round cell amount ${ }^{11}$. With these considerations in mind, the present study was designed to observe the protective role of folinic acid against sterility in an animal model.

\section{Materials and Method:}

The study was carried out on eighteen healthy adult male rats of long Evans Norwegian strain of average weight $210 \mathrm{gm}$. body weight in the Department of Pharmacology, Bangabandhu Sheikh Mujib Medical University, Dhaka, Bangladesh for 24 days. Animals were housed in standard condition and allowed to food and water ad libitum. They were divided into three groups and treated according to Table-I.

At the end of 28 days, the rats were weighed and sacrificed. Their testes were collected for measuring weight, volume and histological examination. Blood was collected for serum testosterone measurement by Radio Immuno Assay in Nuclear Medicine Institute, BSMMU. The testis was fixed in $10 \%$ formol solution, washed in tap water, dehydrated in alcohol, cleaned in xylene and embedded in melted paraffin. Serial sections of 5 micron thickness of testicular tissue were made and stained with Haematoxylin and Eosin (H\&E). Mean values and standard errors were calculated for the number of seminiferous tubules, tubular diameters, spermatozoa containing tubules per microscopic field.

For statistical analysis, Student's ' $t$ ' test was used to compare the results in the experimental groups.

\section{Results :}

The effects of Cyclophosphamide alone (Group-B) and pretreated Folinic acid then Cyclophosphamide (Group-C) on body weight, testicular weight, volume and histology after 28 days in rats are shown in Table II and III. Serum testosterone level in all groups are shown in Table IV.

Histological parameters of control rat showed normal gonadal structure (Fig.-1). The decrease in gross parameters and histological parameters in rats of group B and C were statistically significant (Table II and III , Fig. 2 and Fig. 3). The change of rat body weight, testicular weight and volume, were not statistically significant between the rats of Group-B and $\mathrm{C}$. But there were marked improvements in the number of seminiferous tubules, spermatozoa containing tubules per microscopic field and tubular diameter in rats of Group-C in comparison to rats of Group-B, which was statistically significant (Table II and III, Fig. 2 and Fig. 3).

Differences of Serum testosterone level, in all group of rats were statistically not significant (Table IV).

Table-I

Drug and sacrifice schedule:

\begin{tabular}{|c|c|c|c|c|c|}
\hline Group & $\begin{array}{l}\text { Number of } \\
\text { Rats }(\mathrm{n})\end{array}$ & Drug(s) & $\begin{array}{l}\text { Dose and Route } \\
\text { of administration }\end{array}$ & $\begin{array}{l}\text { Drug dosing } \\
\text { schedule }\end{array}$ & $\begin{array}{c}\text { Date of } \\
\text { sacrifice }\end{array}$ \\
\hline A & 6 & No drug & - & - & At Day 28 \\
\hline B & 6 & Cyclophosphamide & $\begin{array}{l}50 \text { mg/kg/day- } \\
\text { given } \\
\text { Intraperitoneally }\end{array}$ & $\begin{array}{l}\text { From Day } 14 \\
\text { in every } \\
\text { alternate day }\end{array}$ & At Day 28 \\
\hline C & 6 & Folinic Acid & $\begin{array}{c}6 \mathrm{mg} / 500 \mathrm{ml} 5 \% \\
\text { Dextrose in } \\
\text { aqua given orally }\end{array}$ & Everyday & At Day 28 \\
\hline
\end{tabular}


Table - II

Estimation of the weight of the testis in relation to the body weight of the rat.

\begin{tabular}{|c|c|c|c|c|c|c|}
\hline \multirow{2}{*}{$\begin{array}{c}\text { Rat } \\
\text { Groups }\end{array}$} & \multicolumn{3}{|c|}{ Rat Body Weight (Gm) } & \multicolumn{2}{|c|}{ Rat Testes Weight (Gm) } & \multirow{2}{*}{$\begin{array}{c}\text { Testes } \\
\text { Volume }(\mathrm{ml}) \\
\text { Mean } \pm \text { SEM }\end{array}$} \\
\hline & $\begin{array}{c}\text { Initial } \\
\text { weight }\end{array}$ & $\begin{array}{c}\text { Final } \\
\text { weight }\end{array}$ & $\begin{array}{c}\text { Change of } \\
\text { body } \\
\text { weight }\end{array}$ & $\begin{array}{c}\text { Testes weight } \\
(\mathrm{Mg}) \\
\text { Mean } \pm \text { SEM } \\
\end{array}$ & $\begin{array}{c}\text { Testes weight } \\
\text { as Gm\% of final } \\
\text { body weight }\end{array}$ & \\
\hline $\begin{array}{c}A \\
(n=6)\end{array}$ & $211.66 \pm 5.86$ & $293.66 \pm 6.11$ & $+39.49 \pm 5.93$ & $30.9 \pm 0.7$ & $1.04 \pm 0.01$ & $3.11 \pm 0.04$ \\
\hline $\begin{array}{c}B \\
(n=6)\end{array}$ & $212.5 \pm 5.59$ & $248.66 \pm 5.62$ & $+17.01 \pm 1.63$ & $23.5 \pm 0.7^{* * *}$ & $0.93 \pm 0.01^{* * *}$ & $2.71 \pm 0.06^{* * *}$ \\
\hline$\underset{(n=6)}{C}$ & $211.66 \pm 4.94$ & $249.66 \pm 4.73$ & $+18.04 \pm 1.4$ & $23.6 \pm 0.6 \mathrm{NS}$ & $0.94 \pm 0.01 \mathrm{NS}$ & $2.7 \pm 0.05 \mathrm{NS}$ \\
\hline
\end{tabular}

Group-A : normal diet for 28 days without any Drug

Group-B : normal diet for 24 days and received Cyclophosphamide in every alternate day starting from Day 15 up to day28.

Group-C : Folinic acid (6mg in $500 \mathrm{ml}$ of $5 \%$ dextrose in aqua) orally daily for 28 days, and then received Cyclophosphamide in every alternate day starting from day 15 up to day 28.

p-values :

Group A vs Group B : ${ }^{* * *} \boldsymbol{p}<0.001\left[{ }^{* * *}\right.$ Highly significant]

Group B vs Group C : NS $\boldsymbol{p}>0.05$ [NS = Not significant $]$

Table III

Results of Histological parameters

\begin{tabular}{cccc}
\hline $\begin{array}{c}\text { Rat } \\
\text { Groups }\end{array}$ & $\begin{array}{c}\text { Number of } \\
\text { seminiferous tubules } \\
\text { Mean } \pm \text { SEM }\end{array}$ & $\begin{array}{c}\text { Spermatozoa containing } \\
\text { seminiferous tubules } \\
\text { Mean } \pm \text { SEM }\end{array}$ & $\begin{array}{c}\text { Diameter of } \\
\text { seminiferous tubules }(\mu) \\
\text { Mean } \pm \text { SEM }\end{array}$ \\
\hline $\begin{array}{c}\text { A } \\
(n=6) \\
B\end{array}$ & $22 \pm 0.57$ & $97.82 \pm 0.97$ & $287.43 \pm 4.45$ \\
$\left(\begin{array}{c}n=6) \\
C\end{array}\right.$ & $13.83 \pm 0.6^{* * *}$ & $3.43 \pm 1.54^{* * *}$ & $166.66 \pm 6.15^{* * *}$ \\
$(n=6)$ & $18.5 \pm 0.76^{* * *}$ & $47.36 \pm 2.1^{* * *}$ & $214.97 \pm 6.91^{* * *}$ \\
\hline
\end{tabular}

$p$ - values :

Group B vs Group A : *** $\boldsymbol{p}<0.001{ }^{* * *}$ Highly significant]

Group C vs Group B ${ }^{* * *} \boldsymbol{p}<0.001\left[{ }^{* * *}\right.$ Highly significant]

Table IV

Estimation of serum testosterone level

\begin{tabular}{ccl}
\hline Rat groups & $\begin{array}{c}\text { Serum testosterone } \mathrm{nmol} / \mathrm{L} \\
\text { Mean } \pm \text { SEM }\end{array}$ & p-value \\
\hline $\begin{array}{c}\mathrm{A}=6 \\
(\mathrm{n}=6)\end{array}$ & $17.5 \pm 3.81$ & - \\
$\begin{array}{c}\mathrm{B}=6) \\
\mathrm{C}\end{array}$ & $14.16 \pm 3.94 N S$ & Group B vs Group A : NS $p>0.05[\mathrm{NS}=$ Not significant] \\
$(\mathrm{n}=6)$ & $15.33 \pm 4.13 N S$ & Group C vs Group B : NS $p>0.05[\mathrm{NS}=$ Not significant] \\
\hline
\end{tabular}




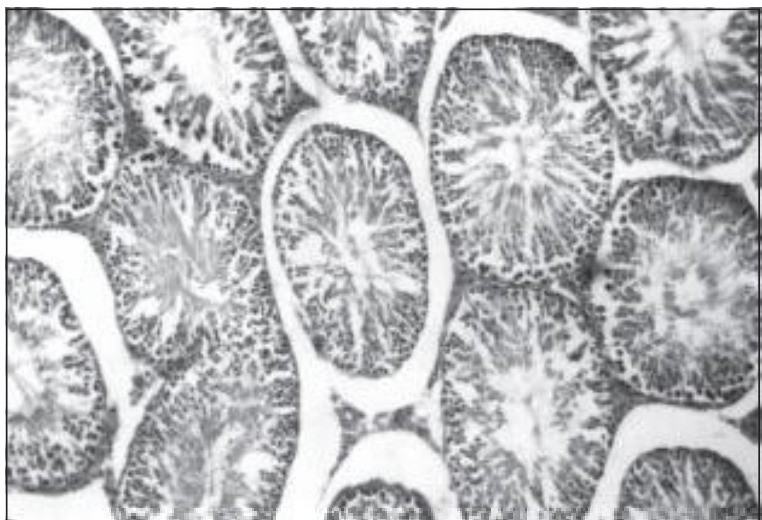

Fig.-1: Photomicrograph showing histological structure of testis in group A-showing normal architecture with normal arrangement of germ cells in the seminiferous tubules and Leydig cells in the interstitial space (H\&E stain, X400).

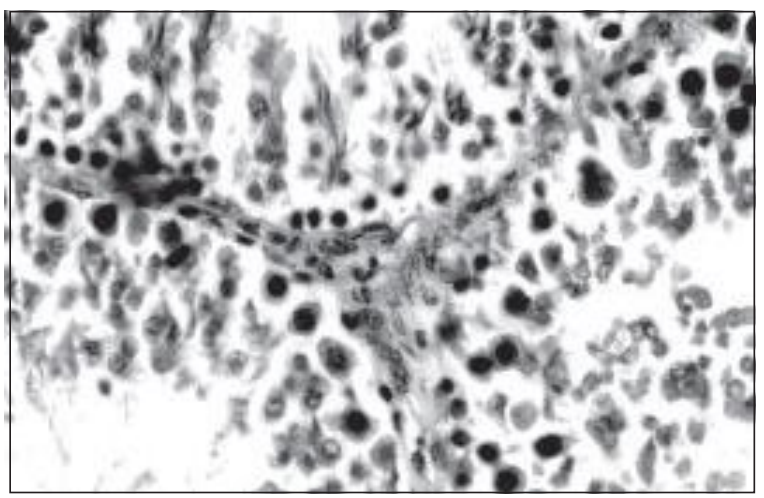

Fig.-2: Photomicrograph showing Cyclophosphamide treated rat testis in Group-B, revealing damage of seminiferous tubules with absence of spermatozoa in the lumen (H\&E stain, X100).

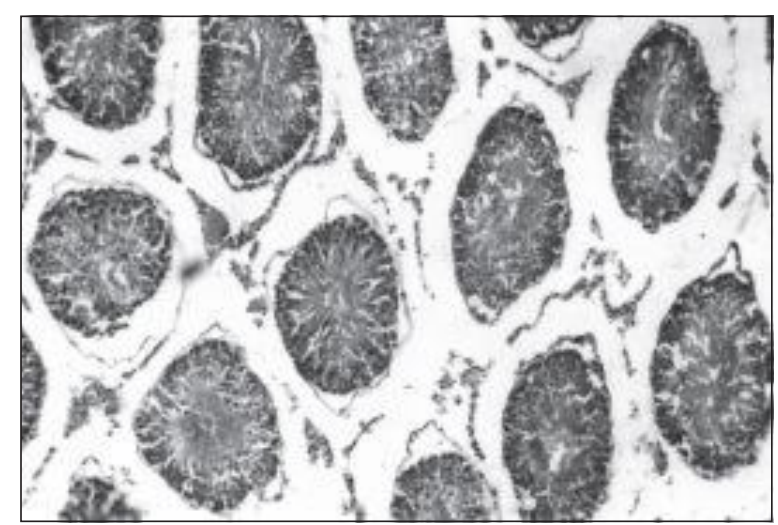

Fig.-3: Photomicrograph showing folinic acid and cyclophosphamide treated rat testes in Group-C, revealing some restoration of seminiferous tubular structure with presence of spermatozoa in some tubules (H\&E stain, X100).

\section{Discussion}

The dose and duration of Cyclophosphamide and Folinic acid treatment in the rats were selected from previous observations ${ }^{11}$. In the present study, Cyclophosphamide was treated for 14 days to ensure damage of all dividing germinal cell in a cycle of seminiferous epithelium ${ }^{12}$. Cyclophosphamide was found to produce testicular damage in rats as evident by significant reduction of body weight, testicular weight $\&$ volume, number of seminiferous tubules, number of spermatozoa containing tubules and mean tubular diameter. The result was consistent with the findings of other investigators who conducted similar type of study 9,10 . Cyclophosphamide has the property of becoming strong electrophiles to target molecules of nucleus of dividing cells. These reaction result in the formation of covalent linkage by alkylation of various nucleofilic moieties such as phosphate, amino, sulfhydryl, carboxyl, and imidazole groups in DNA $^{13}$.

In the present study Folinic acid pre treatment showed significant gonadal protection against Cyclophosphamide. The possible role of folinic acid in preventing testicular damage could be due to effect on mammalian DNA synthesis ${ }^{14,15,16,17}$. As folate cofactors are essential for one carbon transfer reaction involved in de novo synthesis of the purine heterocycles. Inhibition of synthesis of thymidylic acid (2- deoxythymidine monophosphate - dTMP), an essential precursor of DNA, is also suggested ${ }^{16}$. Folates also prevent uracil incorporation into human DNA and thus prevent DNA breakage ${ }^{17}$.

In the present study, Cyclophosphamide had no significant effects on steroidogenesis, as the present cytotoxic dose might had no toxic effects on Leydig cell. These finding closely agree with previous observations ${ }^{9,18}$. The study suggests that folinic acid has got some protective role against testicular damage of rats. Further study in human regarding its dose, duration of treatment and determination of margin of safety are suggested.

\section{References:}

1. Guzick DS. Evaluation of the infertile couple. http://www.uptodate.com/home/index.html . Accessed on July 30, 2011. 
2. Cooper TG, Noonan E, Von Eckardstein S, et al.. "World Health Organization reference values for human semen characteristics". Hum. Reprod 2010.Update 16 (3): 231-45. http:// humupd.oxfordjournals.org/ content/16/3/ 231.full. Accessed on July 30, 2011.

3. Cavallini G. "Male idiopathic oligoasthenoteratozoospermia". Asian J Androl 2006; 8(2):143-157 8 (2): 143 -57. http:// www.nature.com/aja/journal/v8/n2/full/ aja200627a.html. Accessed on July 30, 2011.

4. Hirsh A. "Male subfertility". BMJ 2003; 327 (7416): 669-72. http://www.bmj.com/content/ 327/7416/669.full. Accessed on July 30 , 2011.

5. Swerdloff RS.Causes of male infertility. http:// www.uptodate.com/home/index.html. Accessed on July 30, 2011.

6. $\mathrm{WHO}, 14^{\text {th }}$ Annual report. Spetial program of research, development and research training in Human reproduction, Geneva, December 1985.

7. Macleod J. Human seminal cytology as a sensitive indicator of the germinal epithelium. International Journal of fertility 1964;9:281-95.

8. Shalet SM.Effect of cancer chemotherapy on Gonadal function of patients. Cancer treatment Reviews 1980;7:141-52.

9. Etterdorft JN,West CD PitcockJA\&Williams DL.Gonadal function, Testicular histology and meiosis following cyclophosphamide therapy in patient with nephrotic. The Journal of Pediatrics 1976;88:206-12.

10. Blumfeld Z, and Haim N. Prevention of Gonadal damage during Cytotoxic therapy. The Finish
Medical Society DUODECIM,Ann Med 1997;29:199-206.

11. Bentivoglio G,Melica F and Cristoforoni P. Folic acid in the treatment of Human male infertility and sterility 1993;60(4):698-701.

12. Clermont Y.Kinetics of spermatogenesis in mammals :seminiferous epithelium cycle and spermatogonial renewal .Physiological Reviews, 1972;52(1):198-235.

13. Chu Edward \& Sartorelli Alan C. Cancer Chemotherapy. In Katgung BG, editor. Basic \& clinical Pharmacology. $11^{\text {th }}$ ed. Tata McGrawHill edition 2009; 882-5.

14. Krumdieck CL, Boots LR, Cornwell PE and Butterworth CE.Cyclic variations in folate composition and pteroylpolygluamyl hydrolase(conjugase) activity of rat uterus. The American Journal of clinical nutrition, 1976;29(3):288-94.

15. Butterworth CE, Hatch KD, GoreH, MuellerH, \& Krumdieck CL. Improvement of cervical dysplasia associated with folic acid therapy in user of oral contraceptives. The American Journal Of Clinical Nutrition, 1982; 35: 73-82.

16. Mastes Susan B. Agents used in anemia; Hematopoietic growth factors, in chapter 33, in Katgung BG, editor. Basic and clinical Pharmacology. $11^{\text {th }}$ ed.India: Tata McGraw-Hill edition 2009; 534-6.

17. Ames BN.Micronutrients Prevent Cancerand delay aging. Toxicol-left, 1998;Dec28:102-3.

18. Hooreg J.J. G., Delemae-van de Wall et al. Cyclophosphamide induced disturbance of Gonadotropin secretion manifesting testicular damage. Acta Endocrinologica, 1992; 126: 143-8. 